J. AMER. SOC. HORT. SCI. 117(6):972-975. 1992.

\title{
In Vivo Characterization of a Graft-transmissible, Free-branching Agent in Poinsettia
}

John M. Dole ${ }^{1}$ and Harold F. Wilkins ${ }^{2}$

Department of Horticultural Science and Landscape Architecture, University of Minnesota, St. Paul, MN 55108

Additional index words. Euphorbia pulcherrima, apical dominance, axillary branching, free-branching, restrictedbranching

Abstract. The free-branching poinsettia (Euphorbia pulcherrima Willd. ex. Klotzsch) cultivar Annette Hegg Brilliant Diamond (BD) contained a free-branching agent that was graft-transmissible to the restricted-branching cultivar Eckespoint C-1 Red (CR). CR plants were transformed by the agent regardless of whether BD plants were used as scion or stock, indicating that the agent moved basipetally and acropetally through the graft union. The agent was repeatedly transmitted to a CR plant by serial grafting with a free-branching poinsettia plant. A minimum of 10 days contact through grafting was required for BD plants to transmit the agent to CR plants. Percentage of CR plants exhibiting the free-branching characteristic increased from $0 \%$ for $<10$ days of graft contact with BD plants to $100 \%$ after 30 days.

Stimart (1983) demonstrated that axillary shoot development is promoted in restricted-branching (nonbranching) poinsettias after they are grafted onto free-branching (self-branching) poinsettias. Dole and Wilkins (1991) hypothesized that a freebranching agent exists in the free-branching poinsettia cultivar $\mathrm{BD}$ that is graft-transmissible to the restricted-branching cultivar $\mathrm{CR}$. This agent alters the vegetative characteristics of CR by inducing shoots from the lowermost nodes of pinched plants to develop, in addition to shoots that normally develop from the upper two to three nodes. After grafting to BD, CR leaves are more rounded and less deeply lobed. These changes are retained through two generations of serial vegetative propagation and, therefore, are considered permanent. Reproductive characteristics of anthesis date, cyathia cluster diameter, and bract color are unchanged by the agent. The agent is transmissible from three free-branching cultivars, BD, Annette Hegg Topwhite, and Annette Hegg Hot Pink, to two restricted-branching cultivars, CR and Eckespoint C-1 White.

Some plant pathogens are graft transmissible. Two fungi, Ophiostoma ulmi (Buism.) Nannf. (Dutch Elm Disease) and Ceratocystis fagacearum (Bretz) Hunt (Oak Wilt) are spread by root grafting (Beckman and Kuntz, 1951; Gibbs and French, 1980; Kuntz and Riker, 1950; Neely and Himelick, 1963). Xylella fastidiosa Wells, a xylem-limited bacterium that induces bacterial leaf scorch, also can be transmitted by grafting (Hearon et al., 1980). Further, two mycoplasma-like organisms, causing peach X-disease and pecan bunch disease, can be transmitted experimentally by grafting (Cole, 1937; Sinha and Chiykowski, 1980). Graft propagation transmits several viruses and viroids, including prunus necrotic ringspot virus, apple mosaic virus, hibiscus chlorotic ringspot virus, and citrus exocortis viroid (Semancik, 1980; Sinclair et. al, 1987; Thomas, 1984).

Because the branching agent is graft transmissible, the agent

Received for publication 20 Aug. 1991. Accepted for publication 21 July 1992. Minnesota Agricultural Experiment Station, Scientific Journal Series Paper no. 19101. This research was supported in part by Paul Ecke Poinsettias and the Univ. of Minnesota Computer Center. We thank Doug S. Foulk for his assistance with data collection. The cost of publishing this paper was defrayed in part by the payment of page charges. Under postal regulations, this paper therefore must be hereby marked advertisement solely to indicate this fact.

${ }^{1}$ Assistant Professor. Dept. of Horticulture and Landscape Architecture, Oklahoma State Univ., Stillwater, OK 74078.

${ }^{2}$ Professor. Current address: Nurseryman's Exchange, 2651 Cabrillo Highway North, Half Moon Bay, CA 94019. is hypothesized to be either a pathogenic organism or vectored by a pathogenic organism. The objectives of this study were to expand our knowledge of the agent by determining 1) if the agent can move both acropetally and basipetally through the graft union, 2) if the agent can be repeatedly transmitted by grafting from a free-branching poinsettia to a restricted-branching poinsettia, and 3) the minimum number of days the plants must remain in contact to transmit the agent.

\section{Materials and Methods}

Rooted cuttings were received from Paul Ecke Poinsettias (Encinitas, Calif.) and planted in 10-cm (450-ml) pots filled with a mixture of 3 spaghnum peat: 1 perlite : 1 mineral soil (by volume). Plants were grown in a glasshouse set at a constant $24 \pm 2 \mathrm{C}$. Vegetative conditions were maintained by either natural long days (LD) or incandescent lamps as a $4 \mathrm{~h}$ night interruption (2200 to $0200 \mathrm{HR}$ ). Plants were arranged in a completely randomized design. Data were analyzed by either the analysis of variance (ANOVA) procedure for balanced data or the general linear models (GLM) procedure for unbalanced data (SAS Institute, Cary, N.C.).

A shoot was harvested as a cutting when at least two fully expanded and three to four expanding leaves were present. Cutting bases were treated with rooting powder containing $0.1 \%$ indole-3-butyric acid in talc (Hormex Rooting Powder no. 1, Brooker Chemical, N. Hollywood, Calif.) and rooted under intermittent mist at a constant $21 \pm 2 \mathrm{C}$ air. Rooting medium temperature was maintained at 24 to $27 \mathrm{C}$ using supplemental bottom heat. Standard cultural practices were followed (Ecke et al., 1990).

Stock regeneration (Expt. 1). Scion/stock graft combinations of $\mathrm{BD} / \mathrm{BD}, \mathrm{CR} / \mathrm{CR}, \mathrm{BD} / \mathrm{CR}$, and $\mathrm{CR} / \mathrm{BD}$ were made on 23 and 24 Mar. 1985 using a splice graft (Hartmann and Kester, 1975). Grafted plants were placed under intermittent mist, and all axillary shoots were removed periodically from the stock to prevent competition with the scion. On 10 June, 10 plants of each graft combination were selected randomly for development as stock plants, pinched to the ninth node above the graft union,

Abbreviations: BD, 'Annette Hegg Brilliant Diamond'; CR, 'Eckespoint C-1 Red'; TR, free-branching plants propagated from restricted-branching 'Eckespoint C-1 Red' scions after being grafted onto free-branching 'Annette Hegg Brilliant Diamond' stocks. 
and used for experimental procedures to test for acropetal transmission of the branching agent through the graft union (Dole and Wilkins, 1991). However, for this experiment, five plants of each graft combination were cut back to just below the graft union on 19 Mar. 1986 to force axillary shoot development from the stock. Stocks were allowed to regenerate axillary shoots.

Cuttings were propagated on 11 June 1986, and 15 plants of each graft combination were selected randomly on 16 July. To prevent premature flower initiation, each plant was pinched to three nodes 20 days later and the two lowermost shoots were removed two weeks later. When the acropetal shoot had developed 16 nodes, it was pinched above the 12th node and axillary shoots were allowed to grow. The number of axillary shoots longer than $3 \mathrm{~cm}$ was recorded and leaf morphology was observed 30 days later.

Repeated transmission through grafting (Expt. 2). Cuttings were propagated from scions of the remaining grafted CR/BD plants from Exp. 1 on 14 May 1986. These CR cuttings were free-branching at this time and, therefore, noted as transformed CR (TR). Rooted CR and TR cuttings were planted in a single pot on 18 June and approach grafted (Hartmann and Kester, 1975) when they reached sufficient size, between 14 July and 25 Aug. The following graft combinations were made: TR/TR, TR/CR, CR/TR, and CR/CR. Scion plants were severed below the graft union and stock plants above the graft union 30 days after grafting. At that time, scion shoots were pinched to three nodes above the graft and grafted plants were placed under intermittent mist to reduce transpiration. All axillary shoots were periodically removed except for the terminal shoot on the scion.

When the terminal shoot had developed 16 nodes, it was pinched above the 12th node and axillary shoots were allowed to grow. Cuttings, denoted generation 1, were harvested from scions of the original grafted plants on 15 Jan. 1987. Cuttings were rooted and 16 plants of each graft combination were selected randomly. To prevent premature flower initiation, each plant was pinched to three nodes 20 days later and the two lowermost shoots were removed 14 days later. When the terminal shoot developed 16 nodes, it was pinched above the 12th node and axillary shoots were allowed to grow. The following data were collected 30 days later: leaf characteristics and length, diameter, and number of nodes produced per axillary shoot that developed from the 12 nodes along the main stem. Only the nodes with leaves unfolded off the apical cone were counted on the axillary shoots.

Transmission time (Expt. 3). Four to seven approach grafts of the following combinations were made between 9 June and 14 June 1987: BD/BD, BD/CR, CR/BD, and CR/CR. The graft union was forced apart $0,5,10,15,20,25,30$, or 35 days after grafting, and plants were separated. At that time, plants were cut back to one node above the former graft union, and all axillary shoots were periodically removed except for the acropetal shoot. When the acropetal shoot had developed 16 nodes, it was pinched above the 12th node, and axillary shoots were allowed to grow. The number of nodes with axillary shoots longer than $3 \mathrm{~cm}$ was recorded, and leaf morphology was observed 30 days later.

\section{Results}

Expt. 1. CR stocks with BD scions had $235 \%$ more axillary shoots longer than $3 \mathrm{~cm}$ than with CR scions (Table 1). Graft combinations using BD as stock or scion were not significantly different from each other. CR stocks with BD scions produced leaves that were more rounded and less deeply lobed than the
Table 1. Number of axillary shoots longer than $3 \mathrm{~cm}$ on poinsettia plants propagated from shoots obtained by removal of the scion from auto and reciprocal grafts between free-branching BD and restrictedbranching CR plants. Data were collected 30 days after pinching of plants above the 12th node and means were an average of data from 14 plants. Expt. 1.

\begin{tabular}{lcc}
\hline \hline $\begin{array}{c}\text { Original graft } \\
\text { combinations }\end{array}$ & Stock & $\begin{array}{c}\text { Axillary shoots } \\
>3 \text { cm long } \\
\text { (no.) }\end{array}$ \\
\hline Scion & BD & 11.0 \\
BD & CR & 11.5 \\
BD & BD & 11.4 \\
CR & CR & 3.4 \\
CR & & $* * *$ \\
Significance & & 1.1 \\
HSD (0.05) & & \\
\hline
\end{tabular}

***Significant at $P=0.001$.

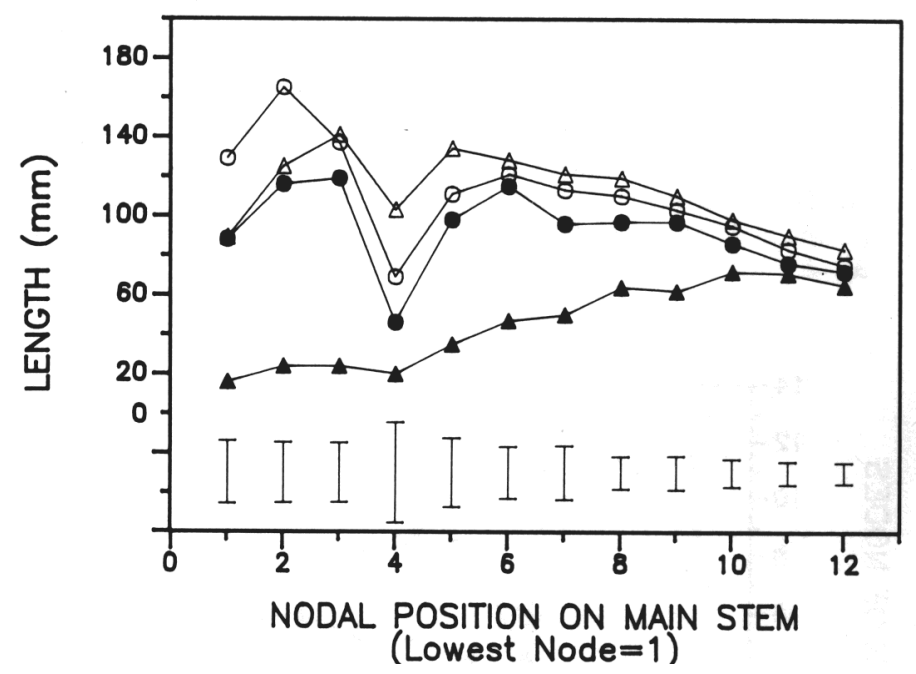

Fig. 1. Axillary shoot length from first generation poinsettia plants propagated from scions of auto and reciprocal grafts between freebranching TR and restricted-branching CR plants. Data were collected on axillary shoots that developed 30 days after pinching of plants above the 12th node and means were an average of data from 16 plants. Vertical bars represent HSD $(P=0.05)$. Expt. 2. Original treatment scion/stock: $\bullet-$ TR/TR; $-\circ \mathrm{TR} / \mathrm{CR} ; \triangle-\triangle \mathrm{CR} / \mathrm{TR}$; $\Delta-\Delta \mathrm{CR} / \mathrm{CR}$.

leaves of CR stocks with CR scions, but were less deeply lobed than leaves produced by BD stocks with either BD or CR scions.

Expt. 2. Numerous changes occurred in CR scions when these were grafted onto transformed CR (TR) stocks as compared to the control graft combination CR/CR. CR/TR axillary shoots were significantly longer for all 12 nodes on the main stem (Fig. 1 ); were significantly thicker for nodes 1 to 9 , but significantly thinner for nodes 11 and 12 (Fig. 2); and had significantly more nodes for nodes 1 to 9 when compared with the control CR/CR axillary shoots (Fig. 3). Leaves of CR/CR combination plants were also more rounded and less deeply lobed than CR/CR leaves, like the leaves of TR/TR and TR/CR plants. These changes were retained in the cuttings propagated from scions of grafted plants for at least three generations of cuttings.

TR/CR axillary shoots were significantly longer at $P=0.05$ for nodes 1 and 2 on the main stem, were significantly thicker for node 2, and had significantly more nodes at nodes 1 and 2 when compared with the control TR/TR axillary shoots (Figs. $1-3)$. 


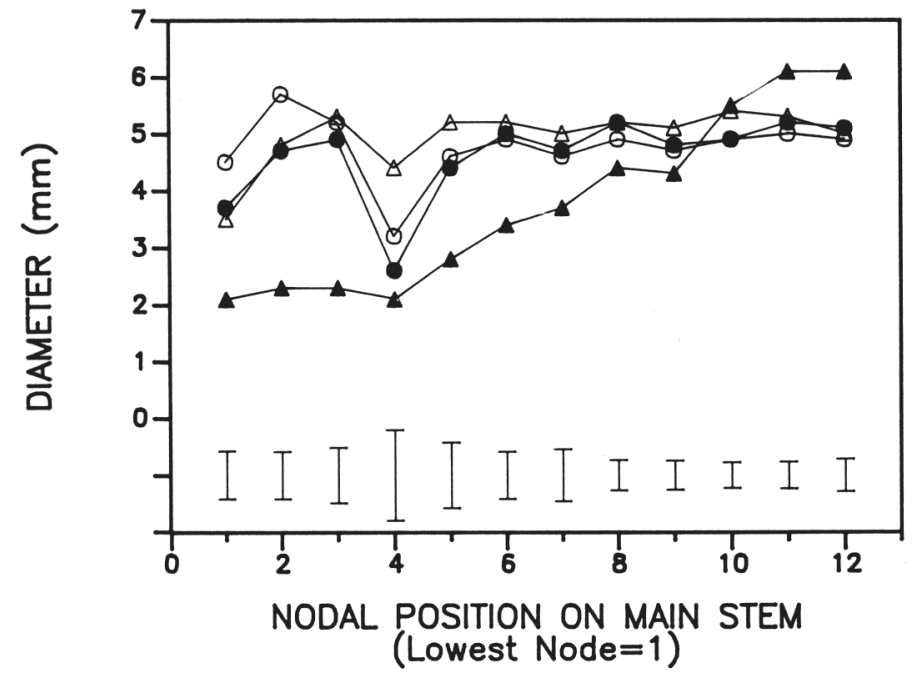

Fig. 2. Axillary shoot diameter from first generation poinsettia plants propagated from scions of auto and reciprocal grafts between freebranching TR and restricted-branching CR plants. Data were collected on axillary shoots that developed 30 days after pinching of plants above the 12th node and means were an average of data from 16 plants. Vertical bars represent HSD $(P=0.05)$. Expt. 2. Original treatment scion/stock: - TR/TR; $\bigcirc-O$ TR/CR; $\triangle-\triangle \mathrm{CR} / \mathrm{TR}$; $\Delta-\Delta \mathrm{CR} / \mathrm{CR}$.

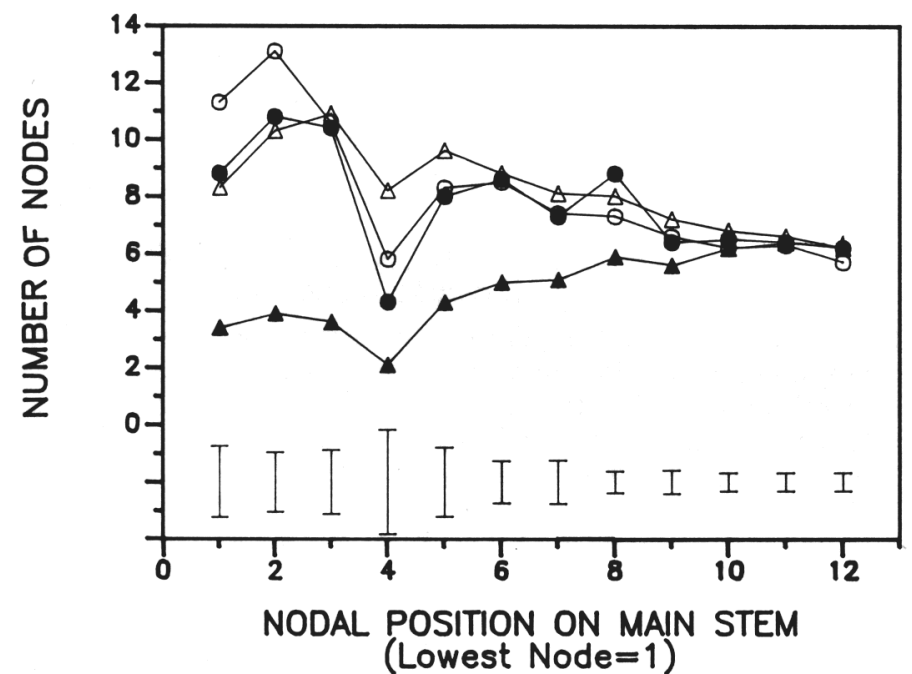

Fig. 3. Number of axillary shoot nodes that developed from first generation poinsettia plants propagated from scions of auto and reciprocal grafts between free-branching TR and restricted-branching CR plants. Data were collected on axillary shoots that developed 30 days after pinching plants above the 12th node and means were an average of data from 16 plants. Vertical bars represent HSD $(P=$ 0.05). Expt. 2. Original treatment scion/stock: $\bullet$ TR/TR; O-O $\mathrm{TR} / \mathrm{CR} ; \triangle-\triangle \mathrm{CR} / \mathrm{TR} ; \Delta-\Delta \mathrm{CR} / \mathrm{CR}$.

Expt. 3. The number of axillary shoots longer than $3 \mathrm{~cm}$ was significantly higher for $\mathrm{CR}$ plants grafted onto $\mathrm{BD}$ plants for 20 , 30, or 35 days than when $\mathrm{CR}$ plants were grafted to $\mathrm{CR}$ plants (Fig. 4). There were no significant differences between $\mathrm{CR}$ plants grafted onto $\mathrm{BD}$ or CR plants if grafted together for only $0,5,10,15$, or 25 days. BD plants grafted to either BD or CR plants were not significantly different, regardless of the number of days grafted together. CR plants grafted to $\mathrm{CR}$ plants produced significantly fewer axillary shoots longer than $3 \mathrm{~cm}$

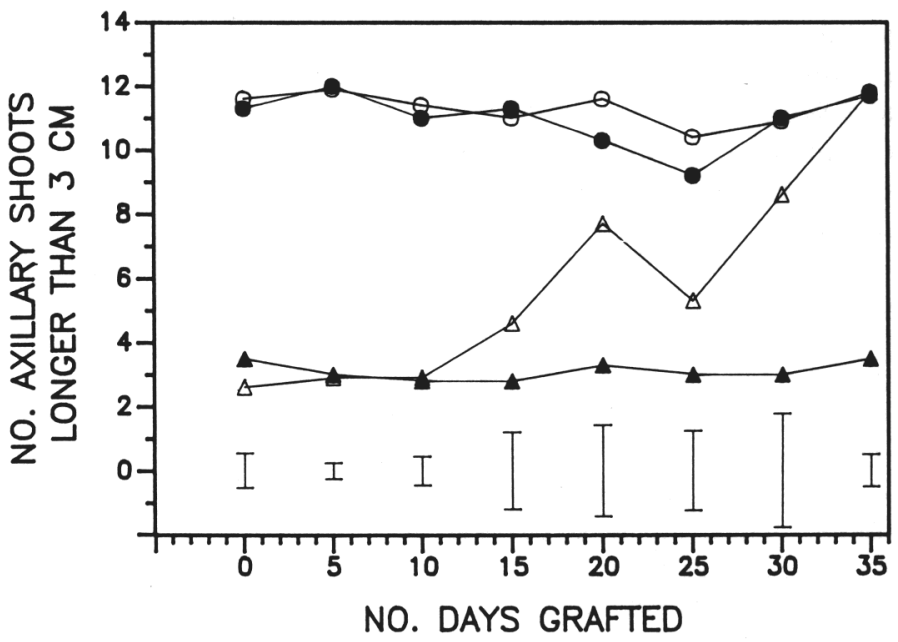

Fig. 4. Number of vegetative axillary shoots longer than $3 \mathrm{~cm}$ on auto and reciprocal approach grafts between free-branching BD and restricted-branching $\mathrm{CR}$ poinsettia plants that had been separated 0 , $5,10,15,20,25,30$, or 35 days after grafting. Data were collected 30 days after pinching plants to the 12th node above the former graft union and means were an average of data from four to seven plants. Vertical bars represent HSD $(P=0.05)$. Expt. 3. Grafted pair: $\bullet$ - $\mathrm{BD}-\mathrm{BD} ; \mathrm{O}-\mathrm{O} \mathrm{BD}-\mathrm{CR} ; \triangle-\triangle \mathrm{CR}-\mathrm{BD} ; \Delta-\Delta \mathrm{CR}-\mathrm{CR}$.

Table 2. Number of CR plants exhibiting altered branching and leaf morphology after being grafted to BD plants for $0,5,10,15,20$, 25,30 , or 35 days before separation. Means are an average of data from 7 plants. Expt. 3 .

\begin{tabular}{lcr}
\hline \hline & \multicolumn{2}{c}{ Plants altered } \\
\cline { 2 - 3 } Days after grafting & (no.) & $(\%)$ \\
\hline 0 & 0 & 0 \\
5 & 0 & 0 \\
10 & 0 & 0 \\
15 & 3 & 43 \\
20 & 6 & 86 \\
25 & 5 & 71 \\
30 & 7 & 100 \\
35 & 7 & 100 \\
\hline
\end{tabular}

than $\mathrm{BD}$ plants grafted to $\mathrm{BD}$ or $\mathrm{CR}$ plants, regardless of the number of days grafted together.

Based on leaf morphology observations, the percentage of CR plants exhibiting the free-branching leaf characteristic increased from $0 \%$ for 0,5 , and 10 days of graft contact to $100 \%$ after 30 days of graft contact (Table 2).

\section{Discussion}

The presumed agent moved acropetally and basipetally through the graft union (Table 1). Previous reports also stated that the agent moved acropetally through the graft union (Dole and Wilkins, 1991; Stimart, 1983). The bi-directional movement of the agent implies that it is carried by the phloem and movement may or may not also occur through the xylem.

Axillary shoot length, diameter, and node count of CR/TR graft combination plants increased when compared to the CR/ CR combination (Figs. 1-3). The results obtained are similar to previously reported increases in axillary shoot length, diameter, and number of nodes produced for CR/BD combination plants when they were also compared to the CR/CR combination plants (Dole and Wilkins, 1991). This result indicates that the agent had not been diluted after being transferred by grafting to CR 
plants from transformed CR (TR) plants. The agent was apparently replicating within CR plants and the free-branching characteristic was not due to the temporary influence of endogenous plant growth substances.

A previous report (Dole and Wilkins, 1991) stated that growth of BD plants may be inhibited after grafting onto $\mathrm{CR}$ plants. However, when TR/CR graft combination plants were compared to TR/TR combination plants, only the axillary shoot length, diameter, and node count at the basipetal nodes 1 and 2 on the main stem were significantly different (Figs. 1-3). The reverse of the previous results occurred: TR/CR combination plants had longer, thicker axillary shoots with more nodes at basipetal nodes 1 and 2 on the main stem when compared to TR/TR combination plants (Figs. 1-3). The stimulation could not have been due to the graft union because data were collected on cuttings from scions of the original grafted plants. The differences between the reports may be due to influence of seasonal changes on branching patterns.

Movement of the agent may depend on development of new vascular tissue between stock and scion. The time required for vascular connections to form between stock and scion can vary depending on the species from 3 days in Lycopersicon esculentum Mill. autografts to 18 days in Kalanchoe blossfeldiana Poelln. autografts (Lindsay et al., 1974; Moore, 1982). Moore and Walker (1981) determined that vascular continuity across the graft interface occurred 10 to 14 days after autografting Sedum telephoides Michx. Stoddard and McCully (1979) noted that xylem first bridged the graft union of pea (Pisum sativum L.) root autografts in 7 days and that phloem bridged in 8 days. A detailed examination of the development of poinsettia graft unions would be necessary to determine if vascular connections are needed for transmission of the agent.

In summary, the agent may be a pathogen or vectored by a pathogen that may be transmitted solely through the vascular system. The agent moved both basipetally and acropetally through the graft union and a minimum of 10 days were required for BD plants to be in contact with $\mathrm{CR}$ plants through grafting in order to transmit the agent. In addition, the agent was apparently replicating or not diluted in the poinsettia because it was transmitted repeatedly to a CR plant by serial grafting with a transformed CR (TR) plant. From previous reports, we also know that, as with some viruses or viroids, the agent can be eliminated during the processes of suspension culture and heat treatment and is not seed transmissible (Preil and Engelhart, 1982; R. Fulton and R. Stewart, personal communications).

\section{Literature Cited}

Beckman, C.H. and J.E. Kuntz. 1951. Translocation of Poisons, dyes, and radioiodine, and its relation to oak wilt. Phytopathology 41:23. (Abstr.)

Cole, J.R. 1937. Bunch disease of pecans. Phytopathology 27:604612.

Dole, J.M. and H.F. Wilkins. 1991. Vegetative and reproductive characteristics of poinsettia altered by a graft-transmissible agent. J. Amer. Soc. Hort. Sci. 116(2):307-311.

Ecke, P., Jr., O.A. Matkin, and D.E. Hartley. 1990. The Poinsettia Manual, 3rd ed. Paul Ecke Poinsettias, Encinitas, Calif.

Gibbs, J.N. and D.W. French. 1980. The transmission of oak wilt. U.S. For. Serv. Res. Paper NC-185.

Hartmann, H.T. and D.E. Kester. 1975. Plant propagation-principles and practices, 3rd ed. Prentice-Hall, Englewood Cliffs, N.J.

Hearon, S.S., J.L. Sherald, and S.J. Kostka. 1980. Association of xylem-limited bacteria with elm, sycamore; and oak leaf scorch. Can. J. Bot. 58:1986-1993.

Kuntz, J.E. and A.J. Riker. 1950. Root grafts as a possible means for local transmission of oak wilt. Phytopathology 40:16-17. (Abstr.)

Lindsay, D.W., M.M. Yeoman, and R. Brown. 1974. An analysis of development of the graft union in Lycopersicon esculentum. Ann. Bot. 38:639-646.

Moore, R. 1982. Graft formation in Kalanchoe blossfeldiana. J. Expt. Bot. 33:533-544.

Moore, R. and D.B. Walker. 1981. Studies of vegetative compatibilityincompatibility in higher plants. I. A structural study of a compatible autograft in Sedum telephoides (Crassulaceae). Amer. J. Bot. 68:820830.

Neely, D. and E.B. Himelick. 1963. Root graft transmission of Dutch elm disease in municipalities. Plant Dis. Rpt. 47:83-84.

Preil, W. and M. Engelhardt. 1982. In vitro separation of chimeras by suspension cultures of Euphorbia pulcherrima Willd. Gartenbauwissenschaft. 47:241-244.

Semancik, J.S. 1980. Citrus exocortis viroid. CMI/AAB Descriptions of Plant Viruses no. 226.

Sinclair, W.A., H.H. Lyon, and W.T Johnson. 1987. Diseases of Trees and Shrubs. Cornell Univ. Press, Ithaca, N.Y. p. 410-411.

Sinha, R.C. and L.N. Chiykowski. 1980. Transmission and morphological features of mycoplasmalike bodies associated with peach $\mathrm{X}$ disease. Can. J. Plant Pathol. 2:119-124.

Stimart, ,D.P. 1983. Promotion and inhibition of branching in poinsettia in grafts between self-branching and nonbranching cultivars. J. Amer. Soc. Hort. Sci. 108:419-422.

Stoddard, F.L. and M.E. McCully. 1979. Histology of the development of the graft union in pea roots. Can. J. Bot. 57:1486-1501.

Thomas, B.J. 1984. Rose mosaic disease: Symptoms induced in roses by graft inoculation with both prunus ringspot and apple mosaic viruses. Plant Pathol. 33:155-160. 